\title{
Terörizmin Türkiye Finansal Piyasaları Üzerine Etkisi: Ampirik Bir Çalışmai
}

\author{
Impact of Terrorism on Financial Markets of Turkey: An Empirical Study
}

\author{
Neşe ALGAN' ${ }^{1}$ Mehmet BALCILAR ${ }^{2}$, Harun BAL ${ }^{3}$, Müge MANGA ${ }^{4}$
}

\begin{abstract}
ÖZET
Bu çalışmada, Türkiye'deki terör eylemlerinin finansal piyasalar üzerindeki etkisinin incelenmesi amaçlanmaktadır. 4 Ocak 1988-24 Mayıs 2016 tarihleri arasındaki günlük veriler ile 16 sektör endeksi kullanılarak yapılan analizde Balcilar vd. (2016) tarafından geliştirilen Parametrik olmayan kantil nedensellik testi kullanılmaktadır. Yapılan analiz sonucunda, terör eylemleri ile finansal piyasalar arasında ortalama getiri bakımından nedensellik ilişkisinin mevcut olmadığı ancak terör eylemlerinin Türkiye'deki turizm, gıda, temel materyaller gibi sektörlerde getiri oynaklığını arttırarak belirsizliğe yol açtığı sonucuna ulaşılmıştır.
\end{abstract}

Anahtar Kelimeler: Finansal piyasalar, Terörizm, Parametrik olmayan kantil nedensellik testi, Türkiye

\section{GíRiş}

Finansal piyasalar, ülkelerin ekonomik, sosyal ve politik alanlarında yaşanan gelişmelerinden hızlı bir şekilde etkilenen piyasalardır. Finansal piyasaların mevcut durumdan etkilenme derecesini belirleyen önemli bir faktör belirsizlik olup belirsizliği yaratan ve arttıran önemli olgulardan birisi de terörizmdir. Terör ve terörizm ile ilgili olarak çok sayıda tanımlama yapılmış olup, her devletin uluslar arası kuruluşlar çerçevesinde yasalarında farklı tanımlamaları bulunmaktadır, Hardman (1937) terörü, önceden belirlenmiş bir hedefi elde etmek için gerekli şiddeti kullanan grubun kullandığı metod şeklinde, Alexander (1982), belirlenmiş hedeflere ulaşabilmek için tabana yayılmış korku dolu bir ortam yaratmak amacıyla organize olmuş bir grubun şiddet kullanması, Johnson (1980), her çeşit siyasi eyleme karşı bilinçli bir şekilde şiddet kullanılması şeklinde tanımlamışlardır (Yayla, 1980). Ulusal, uluslararası,

\begin{abstract}
The purpose of the study is to investigate the impact of terrorism on the Turkish financial market. We test for causality from terrorism index to returns and volatilities of 16 sector level stock indices using daily data from Jan 4, 1988 to May 24, 2016 and a recently developed nonparametric causality-intest test of Balcilar et al. (2016). The results show that there is no causality from terrorist activities to stock market returns. However, we find significant causality at various quantiles from terrorist activates to volatility of tourism, food and basic materials sectors.
\end{abstract}

Keywords: Financial markets, Terrorism, Nonparametric causality-in-quantiles test, Turkey

devlet destekli, transnasyonel, siber ve modern terörizm olmak üzere birçok çeşidi bulunan terör faaliyetlerinin çeşitli özellikleri (Gürel, 2008 ve Alkan, 2002) de bulunmaktadır (Şimşek, 2016).

Terörün niteliğinin ve etkilerinin doğru bir şekilde analiz edilmesi, terörle mücadele politikasının oluşturulmasında büyük bir önem taşımaktadır. Terör eylemleri toplumda sosyal, psikolojik, siyasal ve ekonomik sonuçlar doğurur. Bu sonuçların bir kısmı dolaylı bir kısmı ise dolaysız etkilerdir. Terörün ekonomik sonuçları, terör eyleminin olmasından hemen sonra ortaya çıkarak etkisini çok kısa vadede gösterirken, orta ve uzun vadede de ekonomi üzerinde olumsuz etkiler yaratmaktadır. Terör eylemlerinin ekonomik etkilerinin incelendiği çalışmaların birçoğunda, terörün doğrudan ekonomik maliyetlerinin (can kayıpları, zarar gören altyapı tesislerinin onarımı ve yapımı vb.) terör eylemini takip eden süreçte ortaya çıktığı, dolaylı

'Bu çalışmanın ilk versiyonu 29-31 Ağustos 2016 tarihlerinde Macaristan Koposvar'da düzenlenen 7. Uluslararası Avrasya Ekonomileri Konferansında sunulmuştur.

'Doç. Dr., Çukurova Üniversitesi, nalgan@cu.edu.tr

2Prof. Dr., Doğu Akdeniz Üniversitesi, İşletme Fakültesi, mehmet@mbalcilar.net

${ }^{3}$ Prof. Dr., Çukurova Üniversitesi, İktisadi ve İdari Bilimler Fakültesi, harunbal@cu.edu.tr

${ }^{4}$ Arş. Gör., Çukurova Üniversitesi, İktisadi ve İdari Bilimler Fakültesi, mmanga@cu.edu.tr 
ekonomik maliyetlerinin (tüketici ve yatırımcılar üzerinde yarattığı güvensizlik) ise ülkelere, sektörlere ve zamana göre farklılık gösterdiği ifade edilmektedir.

Abadie ve Gardeazabal (2005)'e göre, uluslararası ekonomi açısından terörizm, fiziksel ve beşeri sermaye stokunda azalışa, yüksek oranda belirsizliğe, üretken olan sektörler yerine güvenlik harcamalarında artışa, turizm, ticaret sektörleri gibi spesifik sektörlerin olumsuz yönde etkilenmesine neden olmaktadır. Frey vd. (2007)'e göre terör eylemleri sonucu piyasalarda: terör eylemlerini önlemeye yönelik artan harcamalar üretim maliyetlerinde artışa, havacilık ve hizmet sektörleri talebinde artışa neden olmakta ve artan belirsizlik düzeyi, risk primini yükseltmektedir. Artan risk pirimi ile birlikte piyasalarda yatırımların azalması, kamu harcamalarının, güvenlik önlemleri kontrollerin, askeri harcamaların vb. artması, istihdam olanaklarının kısıtlanması, tasarruf eğiliminin artması, ülkeden sermaye çıkışlarının artış göstermesi durumları ile karşılaşılmaktadır. Literatürde terör eylemlerinin finansal piyasalar üzerine etkisini inceleyen birçok çalışma bulunmaktadır. $\mathrm{Bu}$ çalışmaların bazıları Tablo 1'de yeralmaktadır.

Tablo 1: Terör Eylemlerinin Finansal Piyasalara Olan Etkisini İnceleyen Çalışmalar

\begin{tabular}{|c|c|c|c|c|}
\hline Yazar/lar & Terör Eylemleri & $\begin{array}{l}\text { Etkilenen } \\
\text { piyasalar }\end{array}$ & $\begin{array}{l}\text { Ekonometrik } \\
\text { Yöntem }\end{array}$ & Bulgular \\
\hline $\begin{array}{l}\text { Chen ve } \\
\text { Siems } \\
(2004)\end{array}$ & $\begin{array}{l}1995 \text { sonrasında } \\
\text { oluşan } 14 \text { terör, } \\
1990 \text { Kuveyt İşgali } \\
\text { ve } 11 \text { Eylül } 2001 \\
\text { terör eylemi }\end{array}$ & $\begin{array}{l}\text { Seçilmiş ülkelerin } \\
\text { finansal piyasaları }\end{array}$ & $\begin{array}{l}\text { Olay etüd } \\
\text { yöntemi }\end{array}$ & $\begin{array}{l}\text { ABD finans piyasasının herhangi } \\
\text { bir terör eylemlemi sonucu eski } \\
\text { haline dönmesi için gerekli olan } \\
\text { sürenin } 40 \text { gün gibi kısa bir süre iken } \\
\text { birçok finansal piyasada bu sürenin } \\
\text { çok daha uzun olduğu sonucuna } \\
\text { ulaşmışlardır. }\end{array}$ \\
\hline $\begin{array}{l}\text { Hon vd. } \\
(2004)\end{array}$ & $\begin{array}{l}11 \text { Eylül } 2001 \\
\text { terör eylemi }\end{array}$ & $\begin{array}{l}25 \text { ülkenin } \\
\text { finansal piyasası }\end{array}$ & GARCH & $\begin{array}{l}11 \text { Eylül terör eylemlerinin hisse } \\
\text { senedi piyasalarına etkilerini } \\
\text { incelemiş ve Avrupa piyasalarına } \\
\text { göre ABD piyasalarında çok daha } \\
\text { kısa zamanda terör eylemlerinin } \\
\text { etkilerinin ortadan kalktığı sonucuna } \\
\text { ulaşmışlardır. }\end{array}$ \\
\hline $\begin{array}{l}\text { Eldor ve } \\
\text { Melnick } \\
(2004)\end{array}$ & $\begin{array}{l}\text { 1990-2003 Filistin } \\
\text { terör eylemleri }\end{array}$ & $\begin{array}{l}\text { İsrail finansal } \\
\text { piyasası }\end{array}$ & $\begin{array}{l}\text { Granger- } \\
\text { Nedensellik } \\
\text { Testi }\end{array}$ & $\begin{array}{l}27 \text { Eylül } 2000 \text { tarihi sonrası yaşanan } \\
\text { Filistin'nin terör eylemlerinden } \\
\text { İsrail menkul kıymetler ve sermaye } \\
\text { piyasasının kalıcı olarak olumsuz } \\
\text { yönde etkilendiği sonucuna } \\
\text { ulaşılmıştır. }\end{array}$ \\
\hline $\begin{array}{l}\text { Karolyi ve } \\
\text { Martell } \\
(2005)\end{array}$ & $\begin{array}{l}\text { 1995-2002 yılları } \\
\text { arasındaki terör } \\
\text { eylemleri }\end{array}$ & $\begin{array}{l}\text { ABD finansal } \\
\text { piyasaları }\end{array}$ & $\begin{array}{l}\text { Olay etüd } \\
\text { yöntemi }\end{array}$ & $\begin{array}{l}\text { Gelişmiş ve demokratik bir ülkedeki } \\
\text { terör eylemlerinin firmaları daha fazla } \\
\text { etkilediği ve bir firma yöneticisinin } \\
\text { zor kullanılarak kaçırılmasının } \\
\text { herhangi bir bina veya tesislere } \\
\text { gerçekleştirilen bombalı eylemlerden } \\
\text { daha büyük çaplı olumsuz etki } \\
\text { yaratacağı sonucuna ulaşılmıştır. }\end{array}$ \\
\hline
\end{tabular}




\begin{tabular}{|c|c|c|c|c|}
\hline $\begin{array}{l}\text { Chulia vd. } \\
\text { (2007) }\end{array}$ & $\begin{array}{l}11 \text { Eylül } 2001 \\
\text { Newyork-11 Mart } \\
2004 \text { Madrid-7 } \\
\text { Temmuz } 2005 \\
\text { Londra terör } \\
\text { eylemleri }\end{array}$ & $\begin{array}{l}\text { ABD ve Avrupa } \\
\text { finansal piyasaları }\end{array}$ & $\begin{array}{l}\text { Multivariate } \\
\text { GARCH }\end{array}$ & $\begin{array}{l}11 \text { Eylül } 2001 \text { 'de meydana gelen } \\
\text { terör eyleminin Avrupa borsasında } \\
\text { dalgalanmaya neden olduğu, } 11 \\
\text { Mart } 2004 \text { Madrid ve } 7 \text { Temmuz } \\
2005 \text { 'te Londra'da meydana gelen } \\
\text { terör eylemlerinin ise ABD borsasının } \\
\text { volatilitesini etkilemediği yönünde } \\
\text { sonuçlar elde etmişlerdir. }\end{array}$ \\
\hline $\begin{array}{l}\text { Arin vd. } \\
\text { (2008) }\end{array}$ & $\begin{array}{l}2002.01- \\
2006.12 \text { zaman } \\
\text { aralığındaki terör } \\
\text { eylemleri }\end{array}$ & $\begin{array}{l}\text { Endonezya, İsrail, } \\
\text { İspanya,Tayland } \\
\text { Türkiye borsası }\end{array}$ & GARCH & $\begin{array}{l}\text { Terör endeksi volatilitesinin borsa } \\
\text { getirilerini etkilediğini, İspanya ve } \\
\text { İngiltere borsasının, diğer ülkelere } \\
\text { kıyasla cabuk toparlandığı sonucuna } \\
\text { ulaşmışlardır. }\end{array}$ \\
\hline $\begin{array}{l}\text { Cam } \\
(2008)\end{array}$ & $\begin{array}{l}11 \text { Eylül Bali ve } \\
\text { Madrid'teki terör } \\
\text { eylemleri }\end{array}$ & $\begin{array}{l}\text { ABD finansal } \\
\text { piyasalar }\end{array}$ & GARCH & $\begin{array}{l}\text { Çalışmada, havayolları, otelcilik ve } \\
\text { eğlence sektörlerinin yapılan terör } \\
\text { eylemlerinden olumsuz etkilendiği } \\
\text { telekomünikasyon ve savunma } \\
\text { sanayisinin olumlu yönde etkilendiği } \\
\text { sonucuna ulaşılmıştır. }\end{array}$ \\
\hline $\begin{array}{l}\text { Nikkinen } \\
\text { vd. (2008) }\end{array}$ & $\begin{array}{l}11 \text { Eylül terör } \\
\text { eylemlerinin } \\
\text { etkilerini ölçmek } \\
\text { amacıyla 10 } \\
\text { Mart 2001- } 12 \\
\text { Mart 2002 } \\
\text { zaman aralığı } \\
\text { kullanılmıştır. }\end{array}$ & $\begin{array}{l}\text { Gelişmiş ülke } \\
\text { (10), Avrupa ülke- } \\
\text { leri (11),Asya ve } \\
\text { Pasifik Bölgesi } \\
\text { (10),Geçiş eko. } \\
\text { (5),Latin Amerika } \\
\text { (7) ve MENA } \\
\text { ülkeleri(10) gru- } \\
\text { bunun finansal } \\
\text { piyasaları }\end{array}$ & GARCH & $\begin{array}{l}\text { Elde edilen sonuçlara göre terör } \\
\text { eylemleri, finansal piyasaların global } \\
\text { ekonomiyle olan ilişkisi düzeyinde, } \\
\text { kısa dönemde negatif yönde } \\
\text { etkilemektedir. }\end{array}$ \\
\hline $\begin{array}{l}\text { Christofis } \\
\text { vd. (2010) }\end{array}$ & $\begin{array}{l}\text { 15.03.1999- } \\
20.11 .2003- \\
27.7 .2008 \text { yıl- } \\
\text { larında yaşanan } \\
\text { terör eylemleri }\end{array}$ & $\begin{array}{l}\text { Türkiye finansal } \\
\text { piyasaları }\end{array}$ & $\begin{array}{l}\text { Olay etüd } \\
\text { yöntemi }\end{array}$ & $\begin{array}{l}\text { Bu eylemlerden borsa piyasasındaki } \\
\text { volatilitenin kısa dönemde anlamlı } \\
\text { olarak negatif yönde etkilendiği } \\
\text { ancak piyasaların hızla toparlandığı } \\
\text { ve terör olaylarının turizm şirket } \\
\text { hisseleri üzerinde etkileri olduğu } \\
\text { ifade edilmiştir. }\end{array}$ \\
\hline $\begin{array}{l}\text { Drakos } \\
(2010)\end{array}$ & $\begin{array}{l}\text { 1994-2004 yılları } \\
\text { arasındaki terör } \\
\text { eylemleri }\end{array}$ & $\begin{array}{l}\text { Seçilmiş } 22 \\
\text { ülkenin finansal } \\
\text { piyasası }\end{array}$ & $\begin{array}{l}\text { Panel Veri } \\
\text { Analiz Yöntemi } \\
\text { ARC(1)-ARC(2) }\end{array}$ & $\begin{array}{l}\text { Terör eylemleri ile borsa getirileri } \\
\text { arasındaki ilişsinin negatif yönde } \\
\text { olduğu sonucuna ulaşılmıştır. }\end{array}$ \\
\hline $\begin{array}{l}\text { Fathi ve } \\
\text { Shahraki } \\
\text { (2011) }\end{array}$ & $\begin{array}{l}29 \text { haziran } 1992- \\
30 \text { Aralık } 2008 \\
\text { arasındaki } 56 \\
\text { terör eylemleri }\end{array}$ & $\begin{array}{l}\text { İran finansal } \\
\text { piyasaları }\end{array}$ & $\begin{array}{l}\text { Paired Sample } \\
\text { T Test }\end{array}$ & $\begin{array}{l}\text { Yapılan analizde yaşanan terör } \\
\text { eylemlerinin Tahran borsası üzerinde } \\
\text { etkili olduğu sonucuna ulaşılmıştır. }\end{array}$ \\
\hline $\begin{array}{l}\text { Kollias vd. } \\
\text { (2011) }\end{array}$ & $\begin{array}{l}11 \text { Mart } 2004 \\
\text { yllında Madrid- } \\
\text { Temmuz } 2005 \\
\text { yilında Londra'da } \\
\text { meydana gelen } \\
\text { terör eylemleri }\end{array}$ & $\begin{array}{l}\text { Petrol fiyatları ve } \\
\text { American S\&P500- } \\
\text { EuropeanDAX, } \\
\text { CAC40 ve FTSE100 } \\
\text { firmaları }\end{array}$ & $\begin{array}{l}\text { non- linear } \\
\text { BEKK- } \\
\text { GARCH }\end{array}$ & $\begin{array}{l}\text { Elde edilen sonuçlara göre, oluşan } \\
\text { terör eylemleri karşısında sadece } \\
\text { CAC40, DAX hisse senetleri ile petrol } \\
\text { fiyatlarının aynı yönlü değişim } \\
\text { gösterdiği, S\&P500, FTSE100 ile } \\
\text { petrol fiyatları arasında herhangi } \\
\text { bir etkileşim oluşmadığı sonucuna } \\
\text { ulaşılmışır. }\end{array}$ \\
\hline
\end{tabular}




\begin{tabular}{|c|c|c|c|c|}
\hline $\begin{array}{l}\text { Chesnesy } \\
\text { vd. (2011) }\end{array}$ & $\begin{array}{l}4 \text { Ocak } 1994 \text { ile } \\
16 \text { Eylül } 2005 \\
\text { arasındaki } 77 \\
\text { terör eylemi }\end{array}$ & $\begin{array}{l}25 \text { seçilmiş } \\
\text { ülkenin finansal } \\
\text { piyasaları }\end{array}$ & GARCH-EVT & $\begin{array}{l}\text { Elde edilen sonuçlarda her } \\
\text { ülkenin finans piyasasının terör } \\
\text { eylemlerinden farklı boyutta } \\
\text { etkilendiğini, en çok etkilenen } \\
\text { borsanın İsviçre iken en az } \\
\text { etkilenenin ise ABD olduğu ifade } \\
\text { edilmiştir. }\end{array}$ \\
\hline $\begin{array}{l}\text { Graham } \\
\text { ve } \\
\text { Ramiah } \\
(2012)\end{array}$ & $\begin{array}{l}\text { 11Eylül Londra, } \\
\text { Bali, Ombay'da } \\
\text { oluşan terör } \\
\text { eylemleri }\end{array}$ & $\begin{array}{l}\text { Japonya finansal } \\
\text { piyasası }\end{array}$ & $\begin{array}{l}\text { Olay etüd } \\
\text { yöntemi }\end{array}$ & $\begin{array}{l}\text { Yapılan çalışmada terör eylemlerinin } \\
\text { bir gün sonrasında Japon piyasasının } \\
\text { negatif yönde etkilendiği sonucuna } \\
\text { ulaşmışlardır. }\end{array}$ \\
\hline $\begin{array}{l}\text { Suleman } \\
\text { (2012) }\end{array}$ & $\begin{array}{l}11 \text { Eylül ABD, } \\
2002 \text { 'de } \\
\text { Bali(2002), 2004'te } \\
\text { Madrid(2004), } \\
\text { Londra'da(2005) } \\
\text { yaşanan terör } \\
\text { eylemleri }\end{array}$ & $\begin{array}{l}\text { Pakistan Karaçi } \\
\text { Menkul Kıymetler } \\
\text { Borsası }\end{array}$ & $\begin{array}{l}\text { EGARCH } \\
\text { modeli }\end{array}$ & $\begin{array}{l}\text { Terör eylemlerinin sektör getirileri } \\
\text { üzerinde negatif etki yarattığı ve } \\
\text { finansal sektör endeksleri üzerindeki } \\
\text { volatiliteyi arttırdığı sonucuna } \\
\text { ulaşmıştır }\end{array}$ \\
\hline $\begin{array}{l}\text { Yıldırım } \\
\text { (2012) }\end{array}$ & $\begin{array}{l}2001 \text { Şubat- } 2010 \\
\text { Ocak döneminde } \\
\text { oluşan terör } \\
\text { eylemleri }\end{array}$ & $\begin{array}{l}\text { Türkiye finansal } \\
\text { piyasalar }\end{array}$ & $\begin{array}{l}\text { Zaman serisi } \\
\text { ve } \\
\text { Olay etüd } \\
\text { yöntemi }\end{array}$ & $\begin{array}{l}\text { Olay çalışması kısmında sivillere } \\
\text { yönelik terör eylemleri ile finansal } \\
\text { piyasalar arasında negatif zaman } \\
\text { serisi analizinde ise altyapı/ tesislere } \\
\text { yönelik geçekleşen terör eylemlerinin } \\
\text { pozitif yönde etkiliği olduğu } \\
\text { sonucuna ulaşılmıştır. }\end{array}$ \\
\hline $\begin{array}{l}\text { Eldor vd. } \\
\text { (2012) }\end{array}$ & $\begin{array}{l}2000-2003 \\
\text { arasındaki } 280 \\
\text { terör eylemi }\end{array}$ & $\begin{array}{l}\text { İsrail ve Filistin } \\
\text { finansal piyasaları }\end{array}$ & GARCH & $\begin{array}{l}\text { İsrail ve Filistin arasında yaşanan } \\
\text { çatışmalar sonucunda İsrail hisse } \\
\text { senetlerinde ortalama } \% 0,43, \\
\text { Filistin hisse senetlerinde ise } \% 0,23 \\
\text { değer kaybı yaşandığı sonucuna } \\
\text { ulaşılmıştır. }\end{array}$ \\
\hline $\begin{array}{l}\text { Bashir vd. } \\
\text { (2013) }\end{array}$ & $\begin{array}{l}01.2005-12.2010 \\
\text { dönemindeki } \\
\text { terör eylemleri }\end{array}$ & $\begin{array}{l}\text { Pakistan Karaçi } \\
\text { Menkul Kıymetler } \\
\text { Borsası }\end{array}$ & $\begin{array}{l}\text { GARCH ve } \\
\text { GARCH-EVT }\end{array}$ & $\begin{array}{l}\text { Çalışmada terör eylemlerinin finansal } \\
\text { piyasalar üzerinde olumsuz etki } \\
\text { yarattığı sonucuna ulaşılış̧ır. }\end{array}$ \\
\hline $\begin{array}{l}\text { Aksoy } \\
(2014)\end{array}$ & $\begin{array}{l}1996-2007 \text { ara- } \\
\text { sında Türkiye- } \\
11 \text { Eylül } 2011 \\
\text { tarihinde ABD'de } \\
\text { gerçekleşen } \\
\text { terör eylemleri }\end{array}$ & $\begin{array}{l}\text { Türkiye finansal } \\
\text { piyasaları }\end{array}$ & $\begin{array}{l}\text { Zaman serisi } \\
\text { ve olay etüd } \\
\text { yöntemi }\end{array}$ & $\begin{array}{l}\text { Olay etüd yöntemi kısmında hisse } \\
\text { senedi piyasasının terör eylemlerini } \\
\text { takip eden günlerde düşmeye devam } \\
\text { ettiği, zaman serisi analizinde ise } \\
\text { Türk Hisse Senedi Piyasasının terör } \\
\text { eylemlerine duyarlı olduğu sonucuna } \\
\text { ulaşılmıştır. }\end{array}$ \\
\hline $\begin{array}{l}\text { Ağırman } \\
\text { vd. (2014) }\end{array}$ & $\begin{array}{l}2003-2011 \text { yılları } \\
\text { arasındaki terör } \\
\text { eylemleri }\end{array}$ & $\begin{array}{l}\text { Seçilmiş } 35 \\
\text { ülkenin finansal } \\
\text { piyasaları }\end{array}$ & $\begin{array}{l}\text { Panel Veri } \\
\text { Analiz Yöntemi }\end{array}$ & $\begin{array}{l}\text { Terör eylemlerinin hisse senedi } \\
\text { piyasaları üzerindeki kısa vadeli } \\
\text { olumsuz etkilerinin, uzun dönemde } \\
\text { piyasa mekanizması tarafından } \\
\text { düzeltildiği sonucuna ulaşılmıştır. }\end{array}$ \\
\hline $\begin{array}{l}\text { Balcılar } \\
\text { vd. (2016) }\end{array}$ & $\begin{array}{l}\text { Her ülke için } \\
\text { farklı zaman } \\
\text { aralığındaki terör } \\
\text { eylemleri }\end{array}$ & $\begin{array}{l}\text { G7 ülkelerinin } \\
\text { finansal piyasaları }\end{array}$ & $\begin{array}{l}\text { Parametrk } \\
\text { Olmayan Kantil } \\
\text { nedensellik } \\
\text { testi }\end{array}$ & $\begin{array}{l}\text { G7 ülkelerinden sadece Japonya ve } \\
\text { belirli ölçüde Birleşik Krallıklardaki } \\
\text { hisse senedi piyasası kendi ülkesi } \\
\text { veya ABD'den kaynaklı oluşan terör } \\
\text { faaliyetlerinden etkilenmektedir. }\end{array}$ \\
\hline
\end{tabular}


Türkiye'de yaşanan terör eylemlerinin birçoğunun eylem stratejilerinde ekonomik hedeflerin bulunması bu eylemleri daha çok dikkat çeker hale getirmektedir. Türkiye'de terör eylemleri, birçok etnik örgüt tarafından gerçekleşmektedir. Son dönemlerde artan ve El-Kaide, DHKP/C, PKK, KCK, ISID gibi birçok örgüt tarafından Türkiye'de gerçekleştirilen terör eylemleri ile ekonomik yapı arasındaki ilişkinin incelenmesi gereğini ortaya çıkarmaktadır.

Terör eylemleri ve teröre hizmet amaçlı atılmış her türlü adım, piyasalarda risk ve belirsizlik unsuru yaratarak finansal piyasaları olumsuz yönde etkilemektedir. Terör eylemlerindeki artış, bilginin de hızlı yayılımı, belirsizliği artırarak risk primlerini yükseltmekte ve beklenen getirilerin azalmasına neden olmaktadır. Ancak finans piyasaları bu tür eylemlerin olumsuz etkilerinden kısa sürede arınabilmektedir. Dalgalanma ve oynaklığın en çok yaşandığı finansal piyasaların terör eylemlerinden nasıl etkilendiği bu aşamada özellikle dikkat çekmektedir. Bu çalışmada, Türkiye'de yaşanan terör eylemlerinin finansal piyasalar üzerine olan etkisi incelenmektedir.

Terör eylemleri ile finansal piyasalar arasındaki ilişkinin incelendiği çalışmalar, üç farklı soru üzerine odaklanmaktadır. Bunlar; terör eylemlerinin borsa getirilerini nasıl etkilediği, menkul kıymetler borsası oynaklığının terör eylemlerine nasıl tepki gösterdiği ve terör eylemleri nedeniyle meydana gelen şokların nasıl uluslararası boyutta yayıldığı şeklinde sıralanabilir. Türkiye üzerine yapılan bu çalışmada, diğer çalışmalardan farklı olarak, Balcılar vd. (2016) tarafından son dönemlerde geliştirilen yeni "Parametrik Olmayan Kantil Nedensellik Testi" ile yukarıda bahsedilen üç farklı soru ele alınmıştır.

Bu çalışmanın giriş bölümünde terör ve finansal piyasalar üzerine etkisi incelenmiş, terör ve menkul kıymetler borsası üzerine yapılmış bazı çalışmalar ve detayları üzerine değerlendirilmeler yapılmıştır. İkinci bölümde çalışmada kullanılacak olan ekonometrik yöntemin teorik yapısı ve BIST (Borsa İstanbul) içerisinde yer alan günlük hisse senetleri getirileri verilmektedir. Üçüncü bölümde yapılan analiz sonucu elde edilen bulgular ve sonuç bölümünde ise çalışmanın analiz kısmında Türkiye üzerine elde edilen sonuçlar doğrultusunda çeşitli değerlendirilmeler yapılmaktadır.

\section{PARAMETRIK OLMAYAN KANTIL NEDENSELLIK TESTI}

Bu çalışmada kullanılan test, Nishiyama vd. (2011), ve Jeong vd. (2012), çalışmalarında yer alan yöntemlerin genelleştirilmesiyle oluşturulmuş ve Balcılar vd. (2016), tarafından ortaya atılmış yeni bir Parametrik olmayan kantil nedensellik testidir. Jeong vd. (2012)'de $x_{t}$ (terör eylemleriendeksi) $\theta^{\prime}$ ıncı kantilde gecikme vektörü $\left\{y_{t-1, \ldots}, y_{t-p}, x_{t-1}, \ldots, x_{t-p}\right\}$ 'ne göre $y_{t}$ 'nin (hisse senedi getirilerinin) Granger nedeni olmaması için,

$Q_{\theta}\left(y_{t} \mid y_{t-1}, \ldots, y_{t-p}, x_{t-1}, \ldots, x_{t-p}\right)=Q_{\theta}\left(y_{t} \mid y_{t-1}, \ldots, y_{t-p}\right)$

olması gerekir. Benzer şekilde $\theta^{\prime}$ ıncı kantilde $\left\{y_{t-1}, \ldots, y_{t-p}, x_{t-1}, \ldots, x_{t-p}\right\}^{\prime}$ e göre, $x_{t}, y_{t}$, değişkeninin eğer,

$$
Q_{\theta}\left(y_{t} \mid y_{t-1}, \ldots, y_{t-p}, x_{t-1}, \ldots, x_{t-p}\right) \neq Q_{\theta}\left(y_{t} \mid y_{t-1}, \ldots, y_{t-p}\right)
$$

ise Granger nedenidir. (2) numaralı denklemde yer alan $Q_{\theta}\left(y_{t} \mid \cdot\right), 0$ ile 1 arasında yer alır $t$ değerine bağlıdır ve $y_{t}$ değişkeninin $\theta^{\prime}$ ıncı kantilini ifade etmektedir. Burada, $Y_{t-1} \equiv\left(y_{t-1}, \ldots, y_{t-p}\right), X_{t-1} \equiv\left(x_{t-1}, \ldots, x_{t-p}\right)$ ve $Z_{t}=\left(X_{t}, Y_{t}\right)$ şeklinde tanımlanmış olup, $F_{y_{t} \mid Z_{t-1}}\left(y_{t} \mid Z_{t-1}\right)$ ve $F_{y_{t} \mid Y_{t-1}}\left(y_{t} / Y_{t-1}\right)$ eşitlikleri sırasıyla $y_{t}$ değişkeninin $Z_{t-1}$ ve $Y_{t-1}$ 'e dayalı koşullu dağılımına ifade etmektedir. $F_{y_{t} \mid Z_{t-1}}\left(y_{t} \mid Z_{t-1}\right)$ 'in tüm $Z_{t-1}$ için $y_{t-1}{ }^{\prime}$ de mutlak olarak sürekli olduğu varsayılır. Eğer $Q_{\theta}\left(Z_{t-1}\right) \equiv Q_{\theta}\left(y_{t} \mid Z_{t-1}\right)$ ve $\quad Q_{\theta}\left(Y_{t-1}\right) \equiv$ ve $Q_{\theta}\left(y_{t} \mid Y_{t-1}\right)$ eşitlikleri tanımlanırsa, $F_{y_{t} \mid Z_{t-1}}\left\{Q_{\theta}\left(Z_{t-1}\right) \mid Z_{t-1}\right\}=\theta$ bir olasıllı ile doğrudur. Sonuç olarak hipotez, 1 . ve 2 . denklemlere yer alan tanımlamalar

$$
H_{0}: P\left\{F_{y_{t} \mid Z_{t-1}}\left\{Q_{\theta}\left(Y_{t-1}\right) \mid Z_{t-1}\right\}=\theta\right\}=1
$$


$H_{1}: \quad P\left\{F_{y_{t} \mid Z_{t-1}}\left\{Q_{\theta}\left(Y_{t-1}\right) \mid Z_{t-1}\right\}=\theta\right\}<1$

şeklinde ifade edilen hipotezler dahilinde sınanmaktadır.

Jeong vd. (2012) çalışmasında $J=\left\{\varepsilon_{t} E\left(\varepsilon_{t} \mid Z_{t-1}\right) f_{Z}\left(Z_{t-1}\right)\right\}$ mesafe ölçütünü kullanılmıştır. Eşitlikte yer alan $\varepsilon_{\mathrm{t}^{\prime}}$ regresyondan elde dilen hata terimini, $f_{Z}\left(Z_{t-1}\right)$ ise $Z_{t-1}$ değişkeninin marjinal olasılık yoğunluk fonksiyonunu ifade etmektedir. Regresyon hatası 3. Denkleme dayalı olarak ortaya çıkmaktadır. Bu denklemde $\mathbf{1}\{\cdot\}$ gösterge fonksiyonu olarak ifade edildiğinde $E\left[1\left\{y_{t} \leq Q_{\theta}\left(Y_{t-1}\right) \mid Z_{t-1}\right\}\right]=\theta$ veya, eş değer bir şekilde, $\mathbf{1}\left\{y_{t} \leq Q_{\theta}\left(Y_{t-1}\right)\right\}=\theta+\varepsilon_{t}$ olacaktır. Jeong vd. (2012), $J \geq 0$ varsayımı altında mesafe ölçütü için

$J=E\left[\left\{F_{y_{t} \mid Z_{t-1}}\left\{Q_{\theta}\left(Y_{t-1}\right) \mid Z_{t-1}\right\}-\theta\right\}^{2} f_{Z}\left(Z_{t-1}\right)\right]$

olduğunu ifade etmektedir. $J=0$ eşitliği söz konusu olduğunda, değişkenler arasında nedensellik ilişkisi olmadığını ifade eden $H_{0}$ hipotezi, $J>0$ olması durumunda geçerli olan $H_{1}$ hipotezine karşı sınanmaktadır. Jeong vd. (2012), J için

$$
\hat{J}_{T}=\frac{1}{T(T-1) h^{2 p}} \sum_{t=p+1}^{T} \sum_{s=p+1, S \neq t}^{T} K\left(\frac{Z_{t-1}-Z_{S-1}}{h}\right) \hat{\varepsilon}_{t} \hat{\varepsilon}_{S}
$$

çekirdek yoğunluk tehmincisini kullanmaktadır. Bu denklemde yer alan $K(),$.$h genişliğinde çekirdek$ fonksiyonunu, $T$, örneklem boyutunu, $p$, gecikme uzunluğunu, $\varepsilon_{t^{\prime}}$ tahmin edilen regresyon hatasını ifade eder ve

$\hat{\varepsilon}_{t}=1\left\{y_{t} \leq \hat{Q}_{\theta}\left(Y_{t-1}\right)\right\}-\theta$

olarak tanımlanır.

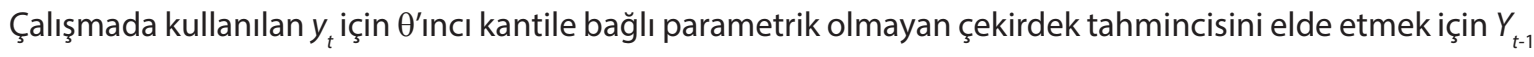
bağlı olarak $\hat{Q}_{\theta}\left(Y_{t-1}\right)=\hat{F}_{y_{t} \mid Y_{t-1}}^{-1}\left(\theta \mid Y_{t-1}\right)$

eşitliği kullanılmaktadır. Eşitlikte yer alan $\widehat{F}_{y_{t} \mid Y_{t-1}}\left(y_{t} \mid Y_{t-1}\right) \quad$ Nadarya-Watson çekirdek tahmin edicisi olup

$\widehat{F}_{y_{t} \mid Y_{t-1}}\left(y_{t} \mid Y_{t-1}\right)=\frac{\sum_{s=p+1, s \neq t}^{T} L\left(\frac{Y_{t-1}-Y_{s-1}}{h}\right) \mathbf{1}\left(y_{s} \leq y_{t}\right)}{\sum_{s=p+1, s \neq t}^{T} L\left(\frac{Y_{t-1}-Y_{s-1}}{h}\right)}$

şeklinde elde edilir. Burada $L(\cdot)$ kernel çekirdek tahmincisi ve $h$ ise bant genişliğidir.

Jeong vd. (2012), çalışmasında yer alan ekonometrik yapı, bu çalışmada 2. moment için genelleştirilmiştir. Bu amaçla Nishiyama vd. (2011) tarafından geliştirilen Parametrik olmayan kantil nedensellik testine benzer bir yöntem izlenmiştir. Daha yüksek düzeydeki momentler için nedenselliği göstermek amacıyla

$y_{t}=g\left(Y_{t-1}\right)+\sigma\left(X_{t-1}\right) \varepsilon_{t}$

denklemini ele alalım. Denklemde yer alan $\varepsilon_{t^{\prime}}$ beyaz gürültü sürecini, $g(\cdot)$ ve $\sigma(\cdot)$ fonksiyonları, durağanlık için belirli şartları sağlayan bilinmeyen fonksiyonları ifade etmektedir. Bu formülasyon $\mathrm{X}_{t-1}{ }^{\prime}$ den $y_{t}^{\prime}$ ye doğru Granger nedenselliğe izin vermemektedir. Fakat, $\sigma(\cdot)$ 'nun doğrusal olmayan genel bir fonksiyonu olması durumunda $\mathrm{X}_{t-1}$ 'den $y_{t}^{2 \prime}$ ye nedenselliğe izin vermektedir. Bu yüzden, varyansta (oynaklıkta) Granger nedensellik için $\mathrm{X}_{t \text { - }}$ , 'in karesinin alınmasına gerek yoktur. Burada, (9) nolu denklemde yer alan varyans nedenselliği için sıfır ve alternatif hipotezler aşağıdaki gibi tekrar formüle edilmiştir: 


$$
\begin{aligned}
& H_{0}: \quad P\left\{F_{y_{t}^{2} \mid Z_{t-1}}\left\{Q_{\theta}\left(Y_{t-1}\right) \mid Z_{t-1}\right\}=\theta\right\}=1, \\
& H_{1}: \quad P\left\{F_{y_{t}^{2} \mid Z_{t-1}}\left\{Q_{\theta}\left(Y_{t-1}\right) \mid Z_{t-1}\right\}=\theta\right\}<1
\end{aligned}
$$

Sıfır hipotezi için ulaşılabilir test istatistiği 10. denklemden ifade edilmiştir ve 6 ve 8 . denklemde yer alan $y_{t}$ değişkeni yerine $y_{t}^{2}$ (hisse senedi getirisinin karesi ya da oynaklık) değişkenine yer verilmiştir.

Jeong vd. (2012) ifade edildiği gibi genel olarak koşullu birinci moment (ortalama) nedensellik ikinci momentte (varyans) nedenselliğin ima eder. Bu sorunu gösterebilmek için

$$
y_{t}=g\left(X_{t-1}, Y_{t-1}\right)+\epsilon_{t} \text {. }
$$

denklemini ele alabiliriz. Burada 1. momentte nedensellğin 2. momenttede nedensellik anlamına geldiği açıktır.

Böylece, daha yüksek mertebeden nedensellik aşağıdaki şekilde test edilebilir:

$$
\begin{aligned}
& H_{0}=P\left\{F_{y_{t}^{k} \mid Z_{t-1}}\left\{Q_{\theta}\left(Y_{t-1}\right) \mid Z_{t-1}\right\}=\theta\right\}=1 \quad k=1,2, \ldots, K, \\
& H_{1}=P\left\{F_{y_{t}^{k} \mid Z_{t-1}}\left\{Q_{\theta}\left(Y_{t-1}\right) \mid Z_{t-1}\right\}=\theta\right\}<1 \quad k=1,2, \ldots, K .
\end{aligned}
$$

(13) nolu denklemden faydalanarak oluşturulan " $x_{t}, K^{\prime}$ ıncı kantile kadar $y_{t}$ 'nin nedenidir" tanımlaması, (6) nolu denklemde her kiçin hesaplanan testistatistiğinedayandırılabilir.Ancakherk $=1,2, \ldots, K$ değerinin 13. denkleme farklı sıfır hipotezleri ile ele alınması dolayısıyla birlikte değerlendirilmesi oldukça zordur. Çünkü bu hipotezler karşılıklı olarak birbiriyle ilişkilidir (Nishiyama vd., 2011). Bu sorunu tatmin edici bir şekilde gidermek için Nishiyama vd. (2011) çalışmasında yer alan ardışık test yöntemi bazı değişikliklerle uyarlanmıştır. İlk olarak birinci momentteki $(k=1)$ düzeyinde nedenselliğin varlığını ifade eden sıfır hipotezinin reddedilmesi, 2. düzeyden de nedenselliğin olmadığını göstermemektedir bundan dolayı $k=2$ düzeyi (2. moment) için test yeniden ardışık olarak yapılır. Sonuç olarak, ortalamada nedenselliği veya veya varyansta nedensellik veya ortalama ve varyansın her ikisinde de nedenselliği ardışık olarak sınayabiliriz.

Kantil nedensellik testi için yapılan ampirik uygulamada 6 . ve 8 . denklemlerde yer alan parametrelerden $h$, bant genişliğini, $p$, gecikme uzunluğunu, $K(\cdot)$ ve $L(\cdot)$ ise çekirdek tipini seçmek gerekmektedir. Çalışmada belirlenen gecikme uzunluğu Schwarz Bilgi Kriterine (SIC) göre belirlenmiştir. SIC kritiği gecikme uzunluğunun belirlenmesinde tutumlu bir kriter olarak bilinir ve bu yüzden parametrik olamayan yaklaşımlar ile ilgili aşırı parametreleşme problemine karşı dirençlidir.
Bant genişliği için en küçük kareler çapraz doğrulama yöntemi kullanılmıştır. $K(\cdot)$ ve $L(\cdot)$, için ise Gauss'çu çekirdeği kullanılmıştır.

\section{VERI ve BULGULAR}

Bu çalışmada yapılan ortalamada ve oynaklıkta (varyansta) nedensellik analizi BIST içerisinde yer alan günlük hisse senedi getirileri için yapılmıştır. Spesifik olarak terör endeksinin günlük hisse senedi getirileri ve/veya oynaklığı üzerinde Granger nedenselliğe sahip olup olmadığı incelenmiştir. İncelenen BIST getirileri arasında Toplam Piyasa, BIST-100 ve BIST-30 olarak 3 adet genel endeks ve ayrıca Bankacılık, Toplam Piyasa, Havayolları, Temel Materyal, İnşaat, Tüketim Malları, Finans, Kamu Hizmetleri, Finansal Hizmetler, Endüstri, Teknoloji, Gıda, Tüketici Hizmetleri, Seyahat, Perakendecilik, Telekomünikasyon, ve Turizm olmak üzere 16 sektör endeksi yer almaktadır. Çalışmada kullanılan günlük veriler 4 Ocak 1988-24 Mayıs 2016 dönemini kapsamaktır. Getiriri serileri Thomson Reuters Datastream veritabanından elde edilmiş olup logaritmik yüzde getiri olarak hesaplanmıştır. Eckstein ve Tsiddon (2004) ve Arin vd. (2008) çalışmalarını izleyerek terör endeksi In (e + ölü sayısı + yaralı sayısı + terör eylemleri sayısı) formülü ile yazarlarca hesaplanmıştır. $\mathrm{Bu}$ endekse temel olan terör eylemlerine ilişkin veriler Dünya Terörizm Olayları RAND Veritabanı (RDWTI) ve Küresel Terörizm veri tabanlarından elde edilmiş olup eksik olan kısımlar 
yazarlarca internet kaynaklarından tamamlanmıştır. $\mathrm{Bu}$ çalışmada kullanılan veriler hem alt sektörel düzeyde olması hem de yüksek frekanslı olması nedeniyle diğer çalışmalardan farklılaşmaktadır.

Tablo 2'de getiri serileri için hesaplanan tanımlayıcı istatistikler verilmektedir. 4 Ocak 1988- 24 Mayıs 2016 günlük getiri serilerinin ortalamalarına bakıldığına en yüksek getirinin Finansal hizmetler ve Endüstri sektörlerinde olduğu görülmektedir. Bu iki sektörü, Teknoloji, Gıda, Bankacilık, Toplam Piyasalar, Temel Materyal, Tüketim Malları ve Kamu hizmetleri takip etmektedir. Standart sapma değerleri incelendiğinde, Seyahat ve Havayolları sektörlerindeki serilerinin göreceli olarak Toplam piyasa ve İnşaat sektörlerine göre daha fazla oynaklık sergilediği görülmektedir. Ayrıca çalışmada, serilerin normal dağılıma sahip olup olmadığının test edilmesinde JB (Jarque- Bera) istatistiğinden yararlanılmıştır. Boş hipotezi "değişken normal dağılıma sahiptir" şeklinde olan JB istatistiği sonuçlarına göre, \%1-\%5 anlamlılık düzeyinde boş hipotez red edilmektedir. Dolayısıyla Tablo 2'ye göre sektörlerin hisse senedi getirileri normal dağılıma sahip değildir. Tanımlayıcı istatistiklerden bir diğeri serilerin beyaz gürültü (ortalaması sıfır, varyansı sabit, ardışık bağımlı olmayan, olasılıklı hata terimi) sürecinden gelip gelmediğinin test edilmesinde kullanılan Ljung- Box testidir. Elde edilen sonuçlar serilerin beyaz gürültü sürecinden gelmediği ifade etmektedir. Tablo 2'de yer alan sonuçlara göre, hisse senedi getiri serilerinde (Hizmetler sektörü haricinde) ARCH etkisinin varlığına ilişkin yüksek kanıtlar tespit edilmiştir. Ayrıca seriler için uygulanan Dickey-Fuller (ADF; 1979) ve Phillips-Perron (PP; 1988), Kwiatkowski, Phillips-Schmidt-Shin (KPSS; 1992) birim kök testleri sonucunda serilerin durağan çıktığı görülmüştür. Aksi takdirde sonuçların güvenirliliğinden şüphe duyulabilecektir. 


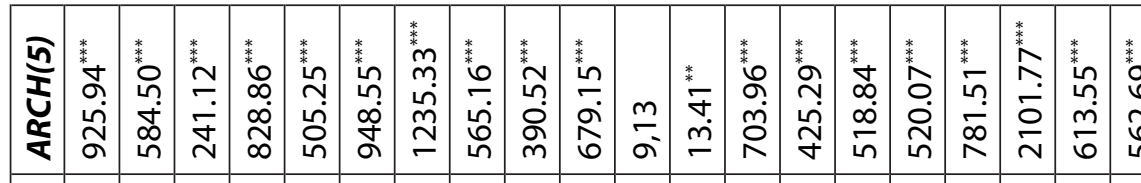

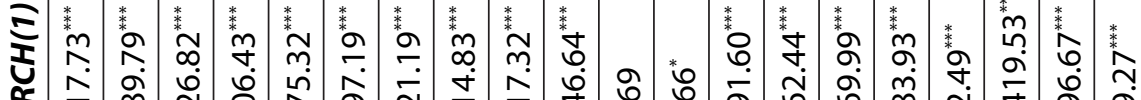

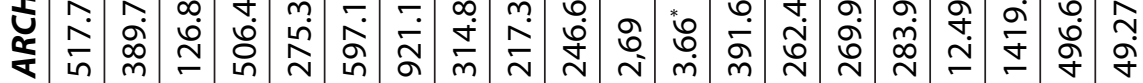

ఐ व̊n

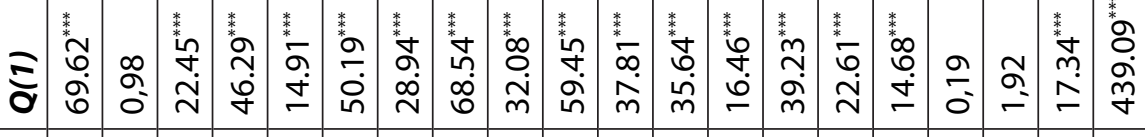

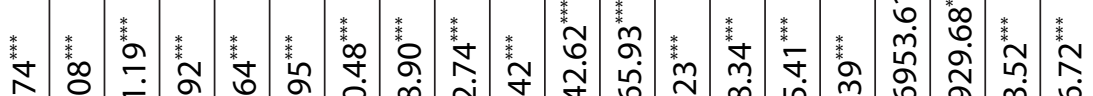

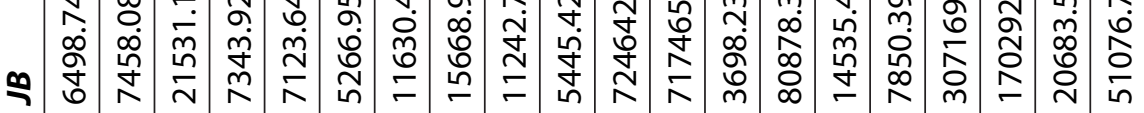

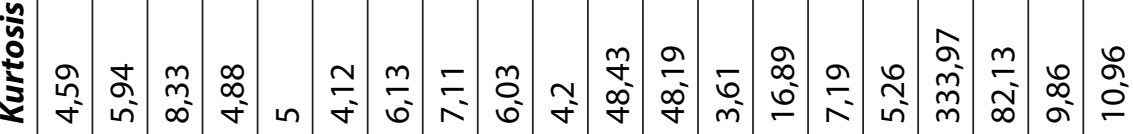
气્气

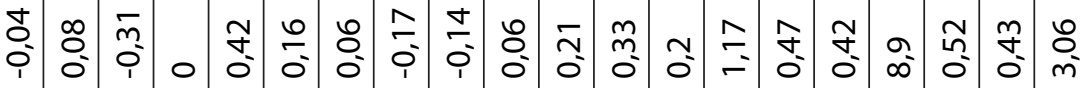

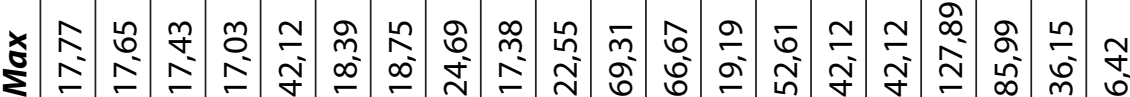

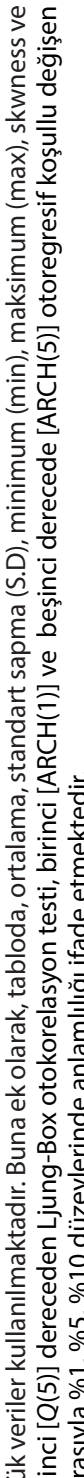

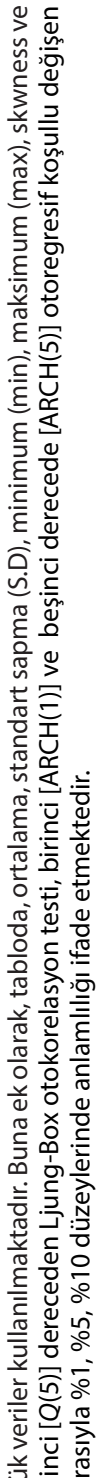

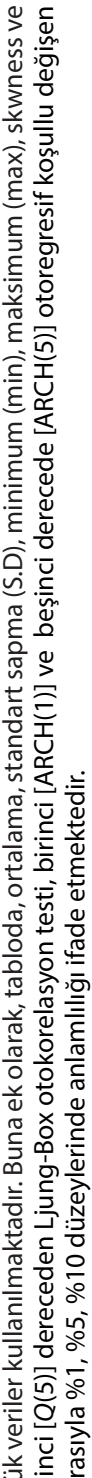

o

乏

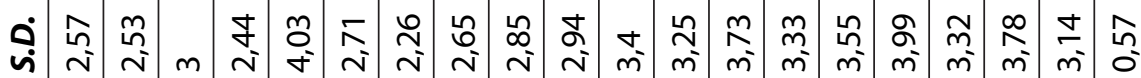

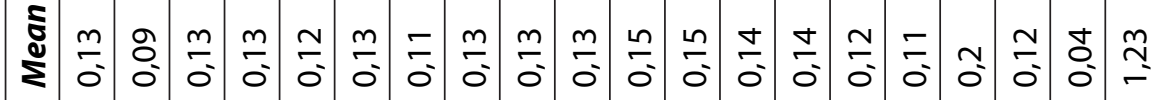

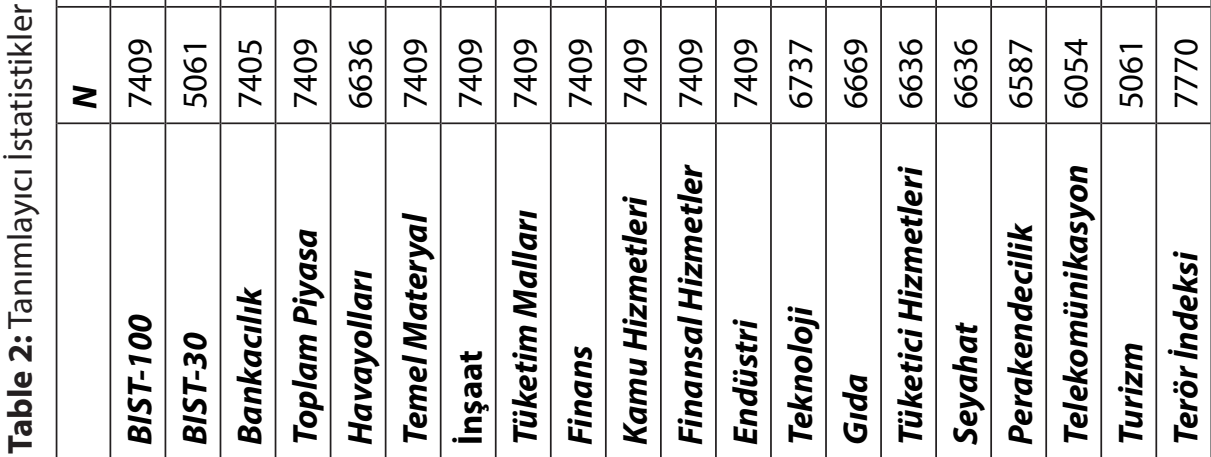

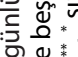

离

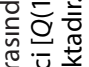

党:

空空离

능

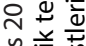

旁蒙

$\sum_{i}$

œ

敢

웜

훙

总空

狺焉皆

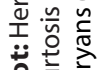

遭高章 
Parametrik olmayan kantil nedensellik testlerine geçmeden önce değişkenler arasındaki ilişki doğrusal Granger nedensellik testi ile incelenmiştir. Uygulanan Doğrusal Granger nedensellik testi sonuçları ek Tablo 1'de yer almaktadır.

Doğrusal Granger nedensellik testinin geçerli olup olmadığının belirlenmesi serilerde doğrusal olmayan bir yapının bulunup bulunmadığının incelenmesi ile olasıdır. Bu amaçla çalışmada BDS (Brock, Dechert, Scheinkman ve Le Baron, 1996) testi kullanılmıştır. Tablo 4'te yer alan sonuçlara göre serilerin tamamında doğrusal olmayan bir yapının söz konusu olduğu açıkça görülmektedir. Buda, doğrusal Granger nedensellik testlerinin geçerli olmadığını göstermektedir.

Table 4: BDS Testi

\begin{tabular}{|c|c|c|c|c|c|}
\hline & $m=2$ & $m=3$ & $m=4$ & $m=5$ & $m=6$ \\
\hline BIST-100 & $22.6715^{* * *}$ & $31.3560^{* * *}$ & $38.7464^{* * *}$ & $47.1968^{* * *}$ & $57.7689^{* * *}$ \\
\hline BIST-30 & $13.9916^{* * *}$ & $20.1147^{* * *}$ & $24.4565^{* * *}$ & $29.0053^{* * *}$ & $34.0266^{* * *}$ \\
\hline Bankacılık & $20.6428^{* * *}$ & $28.6381^{* * *}$ & $37.0649^{* * *}$ & $46.8805^{* * *}$ & $59.8055^{* * *}$ \\
\hline Toplam Piyasa & $21.8461^{* * *}$ & $32.4070^{* * *}$ & $42.1177^{* * *}$ & $54.4296^{* * *}$ & $70.9008^{* * *}$ \\
\hline Havayolları & $24.5049^{* * *}$ & $31.6335^{* * *}$ & $38.2695^{* * *}$ & $46.2281^{* * *}$ & $56.9612^{* * *}$ \\
\hline Temel Materyal & $26.9507^{* * *}$ & $38.0062^{* * *}$ & $50.1333^{* * *}$ & $66.6858^{* * *}$ & $89.7675^{* * *}$ \\
\hline Inşaat & $28.4967^{* * *}$ & $40.3959^{* * *}$ & $55.7840^{* * *}$ & $78.9469^{* * *}$ & $119.4231^{* * *}$ \\
\hline Tüketim Malları & $29.8639^{* * *}$ & $40.9752^{* * *}$ & $53.2788^{* * *}$ & $69.3127^{* * *}$ & $90.8345^{* * *}$ \\
\hline Finans & $18.9468^{* * *}$ & $25.5358^{* * *}$ & $31.5176^{* * *}$ & $37.6347^{* * *}$ & $44.6387^{* * *}$ \\
\hline Kamu Hizmetleri & $26.1147^{* * *}$ & $35.6220^{* * *}$ & $44.7309^{* * *}$ & $56.4563^{* * *}$ & $72.1818^{* * *}$ \\
\hline Finansal Hizmetler & $23.1686^{* * *}$ & $31.6522^{* * *}$ & $38.3837^{* * *}$ & $45.6551^{* * *}$ & $54.5558^{* * *}$ \\
\hline Endüstri & $29.1841^{* * *}$ & $39.9786^{* * *}$ & $50.1871^{* * *}$ & $62.3630^{* * *}$ & $78.8783^{* * *}$ \\
\hline Teknoloji & $27.9151^{* * *}$ & $37.2457^{* * *}$ & $47.1624^{* * *}$ & $60.2392^{* * *}$ & $78.6562^{* * *}$ \\
\hline Gıda & $29.5761^{* * *}$ & $39.7230^{* * *}$ & $50.5224^{* * *}$ & $65.7058^{* * *}$ & $86.5211^{* * *}$ \\
\hline Tüketici Hizmetleri & $30.7813^{* * *}$ & $41.6167^{* * *}$ & $52.5191^{* * *}$ & $67.0972^{* * *}$ & $86.9332^{* * *}$ \\
\hline Seyahat & $25.2578^{* * *}$ & $32.5278^{* * *}$ & $39.5140^{* * *}$ & $47.5950^{* * *}$ & $58.4782^{* * *}$ \\
\hline Perakendecilik & $23.4579^{* * *}$ & $30.2490^{* * *}$ & $36.3530^{* * *}$ & $43.6406^{* * *}$ & $52.8834^{* * *}$ \\
\hline Telekomünikasyon & $24.8147^{* * *}$ & $34.0489^{* * *}$ & $42.6672^{* * *}$ & $53.0183^{* * *}$ & $66.9126^{* * *}$ \\
\hline Turizm & $23.2018^{* * *}$ & $29.6954^{* * *}$ & $36.4242^{* * *}$ & $45.8691^{* * *}$ & $58.3722^{* * *}$ \\
\hline
\end{tabular}

Not: Burada boş hipotez doğrusal, alternatif hipotezi ise doğrusal olmayan bir yapı olduğunu ileri sürmektedir. Bu test VAR modelinden elde edilen kalıntılar üzerine uygulanmıstır. Burada m: korelasyon boyutunu göstermektedir. ${ }^{* * *},{ }^{* * *},{ }^{*}$ sırasıyla \%1, \%5, \%10 düzeylerinde analmlılığı ifade etmektedir.

Hem ortalamada (getiri) hem de varyansta (oynaklık) nedensellik testleri için kullanılan Parametrik olmayan kantil nedensellik testleri seçilen kantil değerlerinde uygulanabilmektedir. Bu amaçla tüm testler $0.10,0.15, \ldots . .0 .85,0.90$ şeklinde 17 kantil değerinde hesaplanmıştır. Kantil testleri uçlarda yere alan kantillerde duyarlılık göstereceğinden 0.10 'dan daha küçük ve 0.90 'dan daha büyük kantiller için test yapılmamıştır.
Grafik 1 seçilen kantil değerlerinde hesaplanan parametrik olmayan getiri ve oynaklık kantil test sonuçlarını göstermektedir. Grafik 1 her bir getiri serisi için hesaplanan getiri (ortalama) Granger nedensellik testini kalın düz çizgi ile, oynaklık (varyans) nedensellik testini kalın kesikli çizgi ile, yüzde 5 önem seviyesindeki kritik değeri de ince düz çizgi ile ayrı ayrı panellerde göstermektedir 
(a) BIST-100

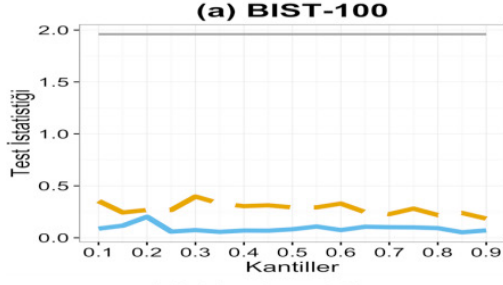

(d) Toplam Piyasa

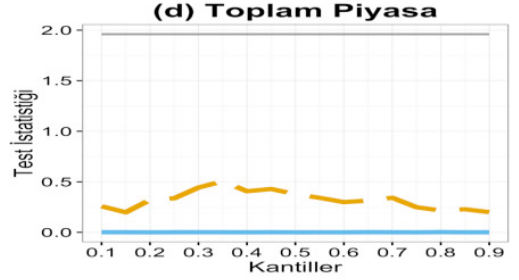

(g) inşaat

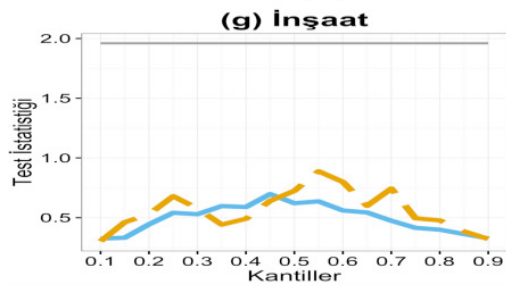

(1) Kamu Hizmetleri

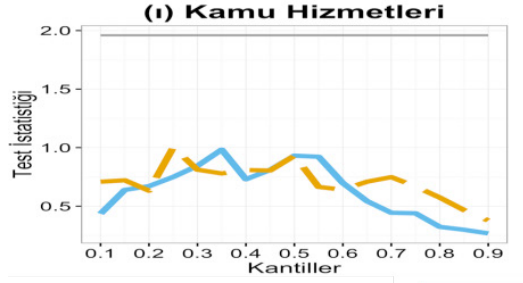

(1) Teknoloji

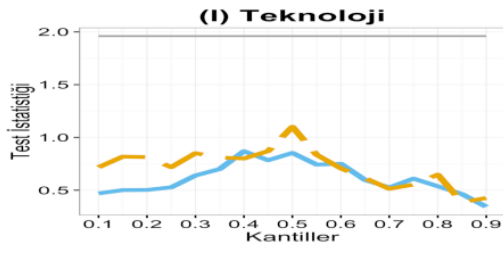

(o) Seyahat

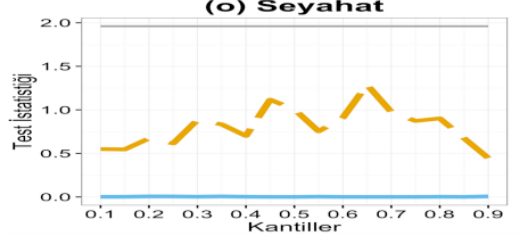

(b) BIST-30

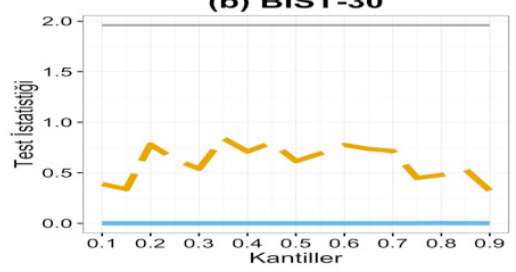

(e) Havayolları

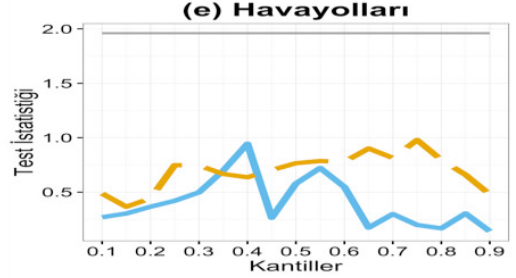

(h) Tüketim Malları

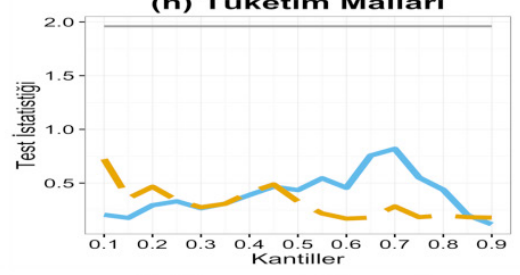

(j) Finansal Hizmetler

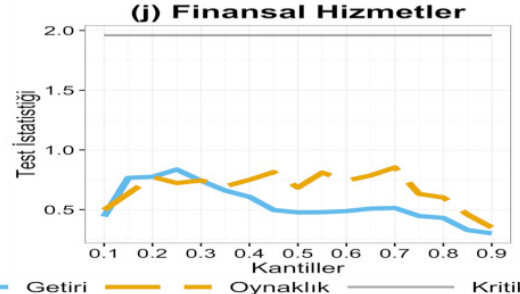

(c) Bankacılık

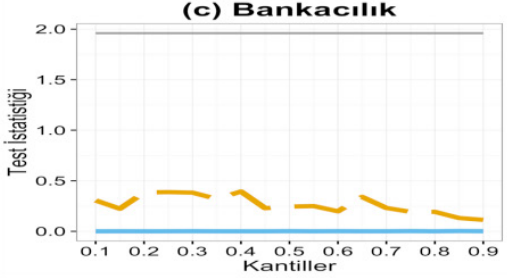

(f) Temel Materyal

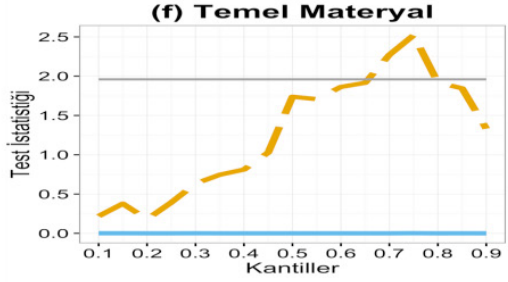

(i) Finans

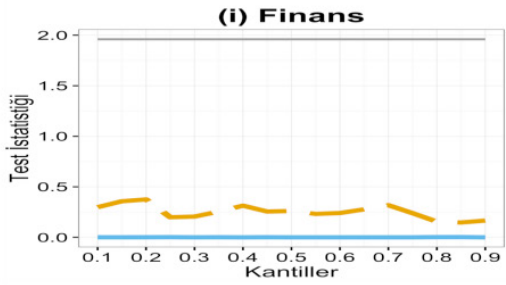

(k) Endüstri

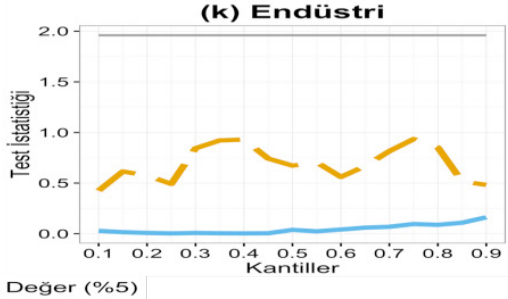

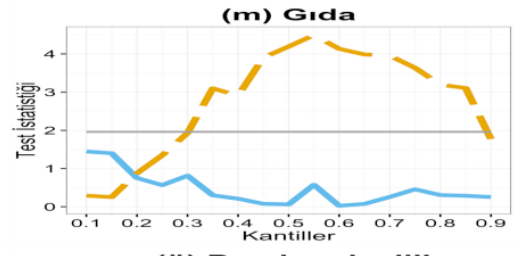

(ö) Perakendecilik

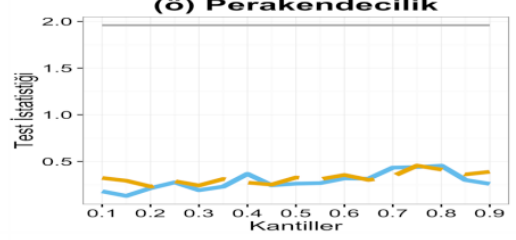

(r) Turizm

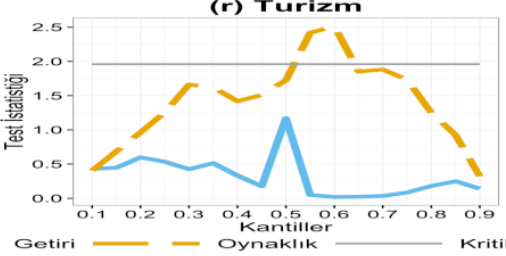

(n) Tüketici Hizmetleri

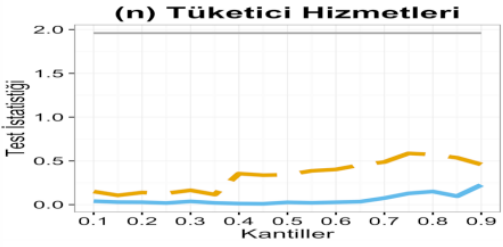

(p) Telekomünikasyon

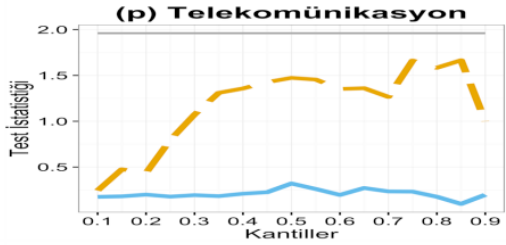

Grafik 1: Parametrik olmayan kantil nedensellik testleri

Grafik 1 incelendiğinde ortaya çıkan en önemli bulgu hiçbir getiri serisi terör endeksinin getiriye (ortalama ya da 1.momentte) Granger neden olmamasıdır. Yüksek frekanslı veri kullanılmasına rağmen Türkiye'de terör eylemleri hisse senetlerinin ortalama getirilerini etkilediğini gösteren bir bulgu elde edilememiştir. Bu durum Turizm, Gıda ve Ulaştırma gibi terör eylemlerine daha duyarlı 
sektörler içinde geçerlidir. Çalışmada elde edilen bulgular, terör eylemlerinin hisse senedi piyasası üzerine negatif yönlü etkisi olduğu sonucuna ulaşan Nikkinen vd. (2008), Drakos (2010), Graham ve Ramiah (2012), Suleman (2012), Yıldııım (2012) çalışmalarıyla farklılık gösterirken, Chulia vd. (2007), Cam (2008), Christofis vd. (2010), Balcılar vd. (2016) çalışmalarıyla benzerlik göstermektedir. Grafik 1'de yer alan test sonuçları incelendiğinde, terör eylemlerinin Temel Materyal, Gıda ve Turizm sektörü hisse senetlerinin oynaklığına bazı kantillerde Granger neden olduğu görülmektedir. Spesifik olarak Temel Materyaller için 0.65-0.80, Gıda için 0.30-0.90, Turizm 0.50-0.65 kantil aralıklarında terör eylemleri oynaklığına Granger neden olmaktadır. Bu sektörlerden Gıda ve Turizm sektörlerinin özellikle turist/ziyaretçi sayısına bağlı sektörler olması dikkat çekicidir. Sonuç olarak, terör eylemleri Türkiye'de menkul kıymetleri piyasalarında ortalama getiriyi etkilememektedir, ancak turizme bağlı getiriye sahip sektörlerde varlık getirilerinin oynaklığı terör eylemlerinden etkilenmektedir.

\section{SONUÇ}

Belirsizlik finansal piyasaların mevcut durumdan etkilenme derecesini belirleyen önemli bir faktördür ve belirsizliği yaratan önemli olgulardan birisi de terörizmdir. Terör eylemleri, belirsizlik ve güvensizliği önemli ölçüde artırmakta, toplumda davranış ve beklentilerde değişikliklere neden olarak ülkelerin makroekonomik yapıları üzerinde olumsuzluklar yaratmaktadır. Terör saldırıları, ülke risk düzeyinin yükselmesine neden olarak turizm ve turizme bağlı sektörleri olumsuz yönde etkilemekte aynı zamanda menkul kıymetler piyasasını da etkileyerek yerli ve yabancı yatııımcıların davranışlarında da değişiklik yaratmaktadır. Özellikle iyi yada kötü haberlere duyarlılığın fazla olduğu sektörlerde oynaklık yüksek olmakta, kötü haberlerin oynaklığı artırmasına karşııık, iyi olayların her zaman oynaklık üzerinde fazla etkisi olmadığı yapılan çalışmalarda vurgulanmaktadır. $\mathrm{Bu}$ aşamada ülkelerin terör gibi kötü haberlerden etkilenme derecesi önem kazanmaktadır.

Buçalışmada,Türkiyemenkul kıymetler piyasasının terör eylemlerine olan tepkisi incelenmektedir. Parametrik olmayan kantil nedensellik testi kullanılan çalışmada Türkiye'deki terör eylemlerinin finansal piyasalar üzerindeki etkileri incelenmektedir. Elde edilen bulgulara göre terör eylemlerinin finansal piyasalar arasında ortalama getiri bakımından nedensellik ilişkisinin olmadığı, ancak gerçekleşen terör faaliyetlerinin finans turizm gibi teröre hassas sektörlerde getiri oynaklığını etkilediği bulunmuştur. Sonuç olarak, terör eylemlerinin ortaya çıkardığı sosyal, ekonomik ve siyasi sorunlar, küresel piyasalardaki güvensizliğin, Türkiye'de turizm, gıda, temel materyaller gibi sektörlerde oynaklığı artırmak suretiyle belirsizliğe neden olduğu söylenilebilir. Elde edilen bu sonucun gereği olarak, ülke k terör eylemlerinden kaynaklı oynaklığın hakim olduğu turizm, gıda ve temel materyaller gibi sektörlerde finansal derinliği arttıracak adımların atılması gerektiği ve finansal piyasalardaki aracı kurumların işlevselliğini arttırması gerektiği ifade edilebilir. 
Ek Tablo 1: Doğrusal Granger Nedensellik Testi ( $P^{*}$ :VAR modeli gecikme uzunluğu)

\begin{tabular}{|l|c|c|}
\hline & $\boldsymbol{H}_{\mathbf{0}}$ :Terör eylemleri hisse senedi getirilerine neden olmaz & $\boldsymbol{p}$ \\
\hline BIST-100 & $1.8226^{*}$ & 10 \\
\hline BIST-30 & 0,7353 & 5 \\
\hline Bankacılık & 1,2744 & 10 \\
\hline Toplam Piyasa & $1.7840^{*}$ & 10 \\
\hline Havayolları & 1,1822 & 10 \\
\hline Temel Materyal & 1,4601 & 10 \\
\hline Inşaat & 1,2178 & 10 \\
\hline Tüketim Malları & 1,5366 & 10 \\
\hline Finans & 1,5024 & 10 \\
\hline Kamu Hizmetleri & $2.1538^{* *}$ & 10 \\
\hline Finansal Hizmetler & 1,4081 & 10 \\
\hline Endüstri & $1.6623^{*}$ & 10 \\
\hline Teknoloji & $1.6304^{*}$ & 10 \\
\hline GIda & 0,3418 & 10 \\
\hline Tüketici Hizmetleri & 1,4101 & 10 \\
\hline Seyahat & 1,3115 & 10 \\
\hline Perakendecilik & $1.7205^{*}$ & 10 \\
\hline Telekomünikasyon & $2.0959^{*}$ & 5 \\
\hline Turizm & 0,9167 & 5 \\
\hline
\end{tabular}

Not: $p$ Bayesci bilgi kriterine göre seçilen vektör otoregresif modelinin gecikme uzunluğunu göstermektedir.

\section{KAYNAKÇA}

Abadie, A. ve Gardeazabal, J. (2005). "Terrorism and the World Economy". European Economic Review, 52(1):1-27

Ağırman, E., Özcan, M. ve Yılmaz, Ö. (2014). "Terörizmin Finansal Piyasalara Etkisi: Ampirik Bir Çalışma”. BDDK Bankacılık ve Finansal Piyasalar, 8(2):99-117

Aksoy, M. (2014). "The Effects of Terrorism on Turkish Stock Market". Ege Akademik Bakış, 14(1):31-41

Arin, K.P., Ciferri, D. ve Spagnolo, N. (2008) "The Price of Terror: The Effects of Terrorism on Stock Market Returns and Volatility". Economics Letters, 101:164167.

Alexande, Y. ve Charles, K.E (ed). (1982), Political Terrorism and Energy: The Threat and Response, Praeger Publishers

Alkan, N. 2002, Gençlik ve Terörizm, Ankara, Temüh Yayınları

Balcilar, M., Bekiros, S. ve Gupta, R. (2016). "The Role of News-Based Uncertainty Indices in Predicting Oil Markets: A Hybrid Nonparametric Quantile Causality
Method", Department of Economics Working Paper Series. 1-17

Balcilar, M., Gupta, R., Pierdzioch, C., \& Wohar, M. (2016). Terror Attacks and Stock-Market Fluctuations: Evidence Based on a Nonparametric Causality-inQuantiles Test for the G7 Countries (No. 201608).

Bashir, U, Gillani, A H, \& Muhammad, S. 2013. "Influence of Terrorist Activities on Financial Markets: Evidence from KSE". Financial Assets and Investing, (2), p. 5-13

Brock W.A., Dechert D, Lebaron B. ve Scheinkman J. (1996) "A test for independence based on a correlation dimension", Econometric Review, 15:197-235

Cam, M. A. (2008) "The impact of terrorism on United States industries". Economic Papers: A journal of applied economics and policy, 27(2):115-134.

Chen, A.H. ve Siems, T.F. (2004)"The Effects of Terrorism on Global Capital Markets". European Journal of Political Economy, 20:349-366.

Chesney, M. Reshetar, G. ve Karaman, M. (2011)“The Impact of Terrorism on Financial Markets: An 
Empirical Study". Journal of Banking and Finance, 35 (2):253- 267.

Christofis, N. Kollias, C., Papadamou, S. ve Stagiannis, A. (2010) "Terrorism and Capital Markets: The Effects of the Istanbul Bombings". Economics of Security Working Paper 31

Chuliá, H., Climent, F.J., Soriano, P. ve Torró, H. (2009) "Volatility transmission patterns and terrorist attacks"Quantitative Finance, 9 (5), p. 607-619.

Drakos, K. (2010) "Terrorism Activity, Investor Sentiment and Stock Returns". Review of Financial Economics, 19 (3):128-135.

Eckstein, Z. ve Tsiddon, D. (2004) "Macroeconomic Consequences of Terror:Theory and the Case of Israel". Journal of Monetary Economics, 51 (5):971-1002.

Eldor, R. R., Hauser, S., Kroll, Y. ve Shoukair, S. (2012) "Financial Markets and Terrorism: The Perspective of The Two Sides of The Conflict". Journal of Business Administration Research, 1:18-29.

Eldor, R.,ve Melnick, R. (2004). "Financial Markets and Terrorism". European Journal of Political Economy, 20:367-386.

Fathi, S. ve Sahahraki, K. (2011) "Effect of Terrorism on Financial Markets", Interdisciplinary Journal of Contemporary Research in Business, 3 (5): 249-255

Frey, B., Luechinger, S., ve Stutzer, A. (2007)“Calculating Tragedy: Assessing the Costs of Terrorism", Journal of Economic Surveys, (21):1-24

Global Terrorism Database, (2016). Global Terrorism Index. https://www.start.umd.edu/gtd/ (20.03.2016)

Graham, M. A. ve Ramiah, V. B. (2012).“Global Terrorism and Adaptive Expectations in Financial Markets: Evidence from Japanese Equity Market". Research in International Business and Finance, 26(1):97-119.

Gürel, M. M. (2008). "Küreselleşen Dünya ve Terörizm”, Yayınlanmamış Yüksek Lisans Tezi, Kadir Has Üniversitesi Sosyal Bilimler Enstitüsü

J.B.S. Hardman: "Terrorism", Encyclopedia of the Social Sciences (yön. E.R. Seligman; New York: Macmillan, 1936), 578.s. Ayrica: R. Gaucher, Les Terroristes (Paris: Albin Michel, 1965), s. 24

Hon, M.T., Strauss, J., ve Yong, S.Y. (2004) “Contagion in Financial Markets After September 11: Myth or Reality?", Journal of Financial Research, 27:95-114.
Johnson, P. (1980) "The Seven Deadly Sins Of Terrorism, International Terrorism: challenge and Response" ed. Benjamin Netayahu, Jelusalem: The Jonathan Institue, 15

Jeong, K., Härdle, W. K. ve Song, S. (2012). "A Consistent Nonparametric Test for Causality in Quantile". Econometric Theory, 28:861-887.

Karolyi, A., ve Martell, R., (2010). "Terrorism and The Stock Market". International Review of Applied Financial Issues and Economics, 2,:285-314.

Kollias, C., Papadamou, S. ve Stagiannis, A. (2011). "Terrorism and Capital Markets: The Effects of The Madrid and London Bomb Attacks". International Review of Economics \& Finance, 20(4):532-541.

Nikkinen, J., Omran, M., Sahlstrom, P., ve Aijo, J. (2008). "Stock Returns and Volatility Following The September 11 Attacks: Evidence from 53 Equity Markets". International Review of Financial Analysis, 17 (1):27-46

Nishiyama, Y., Hitomi, K., Kawasak, Y., ve Jeong, K., (2011). "A Consistent Nonparametric Test for Nonlinear Causality - Specification in Time Series Regression". Journal of Econometrics, 165:1 12-127.

RAND Database (2016) Worldwide Terrorism Incidents, http://www.rand.org/nsrd/ projects/ terrorism-incidents.html, (Erişim tarihi: 03.06.2016)

Şimşek,M.(2016).“Terörizm: Kavramsal Bir Çalişma", Akademik Bakış Dergisi,54:319-335

Suleman T. M. (2012). "Stock market reaction to terrorist attacks:Empirical evidence from a front line state". Australasian Accounting, Business and Finance Journal, 6(1):97-110.

Thomson Reuters Datastream (2016) http://financial. thomsonreuters.com/en/products/data-analytics/ financial-news-feed.html (Erişim tarihi: 01.06.2016)

Yayla,A.(1980),“Terörizm:Kavramsal Bir Çerçeve"A.Ü.Siyasal Bilgiler Fakültesi Dergisi,45(1):335-385.http://www.politics.ankara. edu.tr/dergi/pdf/45/1/atillayayla.pdf. (25.05.2016)

http://www3.weforum.org/docs/TT15/WEF_Global_ Travel\&Tourism_Report_2015.pdf(04/11/2016.

Yıldırım M. (2012), "The Effect of Terrorism on Stock Market: Turkish Experience", http://www.academia. edu/7904736/_The_Effect_of_Terrorism_on_Stock_ Market_Turkish_Experience_(25.05.2016) 